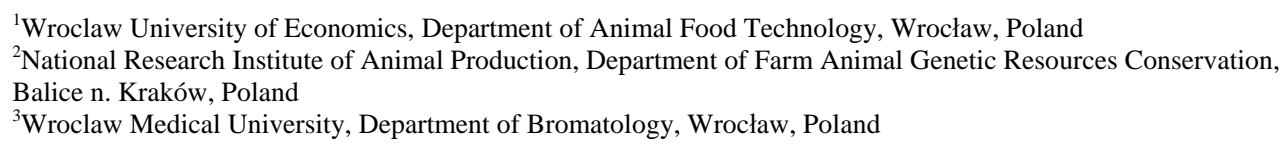

ANDRZEJ OKRUSZEK ${ }^{1}$, JULIUSZ KSIĄŻKIEWICZ² ${ }^{2}$ JANINA WOŁOSZYN ${ }^{1}$, TOMASZ KISIEL ${ }^{2}$, AGNIESZKA ORKUSZ ${ }^{1}$ and JADWIGA BIERNAT ${ }^{3}$

\title{
Effect of laying period and duck origin on egg characteristics
}

\begin{abstract}
The study was carried out on eggs of two-year-old Orpington ducks (O1) and crossbred ducks Khaki Campbell $\times$ Orpington $(\mathrm{KhO})$. Eggs for analysis were collected in the $6^{\text {th }}$ and the $22^{\text {nd }}$ week of egg laying. The eggs of KhO ducks had greater weight $(72.45 \mathrm{~g})$, specific gravity $\left(1.083 \mathrm{~g} / \mathrm{cm}^{3}\right)$ and a thicker shell $(0.67 \mathrm{~mm})$ in comparison to eggs of the $\mathrm{O} 1$ population $\left(70.64 \mathrm{~g}, 1.081 \mathrm{~g} / \mathrm{cm}^{3}\right.$ and $0.65 \mathrm{~mm}$, respectively). Eggshell content accounted for $9.53 \%$ and $7.85 \%$ of egg weight in $\mathrm{KhO}$ and $\mathrm{O} 1$ ducks, respectively. Eggs of KhO ducks were characterized by a lower egg white index (0.07), yolk content (39.48\%) and protein content of egg white as well as lower $\mathrm{L}^{*}$ parameter of yolk than eggs of $\mathrm{O} 1$ ducks. In KhO eggs, yolk lipids contained more C 18:1 cis-9, C 20:4, C 22:6 and C 20:5 and less $\alpha$ C 18:3 and C 18:1 trans-11 fatty acids than those of O1 eggs. The eggs laid in the $6^{\text {th }}$ week had greater weight (by $3.61 \mathrm{~g}$ ), specific gravity (by $0.01 \mathrm{~g} / \mathrm{cm}^{3}$ ), egg white content (by 2.26\%), eggshell thickness (by $0.04 \mathrm{~mm}$ ), strength (by $10.70 \mathrm{~N}$ ) and deformation (by $0.90 \%$ ), and lower yolk content (by $2.34 \%$ ) than the eggs laid in the $22^{\text {nd }}$ week of laying. Furthermore, the eggs laid at the beginning of the second laying period were characterized by higher protein content of egg white and yolk (by $0.26 \%$ and $0.49 \%$ respectively) and $\mathrm{pH}$ value of egg white and yolk, lower lightness of yolk $\left(\mathrm{L}^{*}\right)$, higher unsaturated fatty acids (UFA) content of yolk (especially polyunsaturated fatty acids - PUFA, by 2.53\%), and lower saturated fatty acids (SFA) content of yolk (by 3.10\%) and total cholesterol content (by 2.38\%).
\end{abstract}

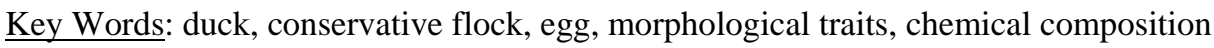

\section{Zusammenfassung}

Titel der Arbeit: Der Einfluss der Legeperiode auf Eimerkmale bei zwei bodenständigen Entenpopulationen

Die Untersuchungen wurden an Eiern von 2 Jahre alten Orpington Enten (O1) und einer Kreuzung aus Khaki Campell und Orpington (KhO) durchgeführt. Die Eier für die Analyse wurden in der 6. und 22. Woche der Legeperiode gewonnen. Die Eier der KhO Enten hatten ein höheres Gewicht (72,45 g), spezifische Dichte (1,083 $\left.\mathrm{g} / \mathrm{cm}^{3}\right)$ und eine dickere Schale $(0,67 \mathrm{~mm})$ im Vergleich zu den Eiern der O1 Population $\left(70,64 \mathrm{~g}, 1,081 \mathrm{~g} / \mathrm{cm}^{3}\right.$ and 0,65 mm). Der Eierschalengehalt machte 9,53\% und 7,85\% des Eigewichtes in KhO und O1 Enten aus. Die Eier der KhO Enten sind gekennzeichnet durch einen geringeren Eiweiß-Index (0,07), Eigelb- (39,48 \%) und Proteingehalt des Eiweißes als auch einen niedrigeren $\mathrm{L}^{*}$ Parameter des Eigelbs im Vergleich zu den O1 Eiern. In KhO Eiern enthielt das Eigelb mehr C 18:1 cis-9, C 20:4, C 22:6 und C 20:5 und weniger C 18:3 und C 18:1 trans-11 Fettsäuren als bei O1 Eiern beobachtet wurde. Die Eier, die in der 6. Woche gelegt wurden, hatten ein erhöhtes Gewicht (um 3,61 g), erhöhte Dichte (um 0,01 g/ $\mathrm{cm}^{3}$ ), einen erhöhten Eiweißgehalt (um 2.26 \%), eine dickere Eierschale (um 0,04 mm) und eine niedrigeren Eigelbgehalt (um 2,34 \%) als die Eier, die in der 22. Woche gelegt wurden. Außerdem waren die Eier, die zu Beginn der 2. Legeperiode gelegt wurden, gekennzeichnet durch höheren Proteingehalt im Eiweiß und Eigelb (um 0,26 und 0,49 \%) und im pH Niveau, sowie einen niedrigeren L* Parameter des Eigelb, höherer Anteile an ungesättigten Fettsäuren (UFA) im Eigelb (besonders mehrfach ungesättigte Fettsäuren - PUFA, um 2,53 \%) und niedrigerer gesättigter Fettsäuren im Eigelb (um 3,10 \%) sowie Cholesterin (um 2,38 \%).

Schlüsselwörter: Ente, bodenständige Population, Ei, morphologische Eigenschaften, chemische Zusammensetzung

\section{Introduction}

There are eight flocks of ducks included in the duck conservation programme in Poland. The conservative flocks of ducks kept in situ are a source of genetic variability 
which allows breeding work to be continued (KSIĄŻKIEWICZ, 1995). From the point of view of breeding maintaining genetically diversified conservative flocks of birds it is necessary to give rise to genetic variation in the selected populations. Ducks kept in small populations are particularly susceptible to the intense effects of inbreeding and genetic drift (KSIAZŻKIEWICZ, 2003). These unique populations are characterized by good production traits, which are the basis of studies on traits such as meat quality (KISIEL and KSIĄŻKIEWICZ, 2004) or egg quality (KSIĄŻKIEWICZ et al., 1999; KSIAZŻKIEWICZ and KISIEL, 2002b). The eggs of ducks were studied to determine the interbreed variability of the species (KSIAZŻKIEWICZ and BEDNARCZYK, 1996) and their usefulness for the food industry (PIKUL, 1998). Even though eggs of domestic fowl constitute an important source of protein in the human diet (POWRIE and NAKAI, 1986), duck eggs containing approx. 53\% egg white and 35\% yolk are not used for consumption and processing in Poland.

Some properties of eggs, such as egg weight, egg specific gravity, eggshell thickness, egg shape index and egg white and yolk index in two-year-old duck eggs collected during the entire laying period were the subject of earlier studies by KSIAZŻKIEWICZ and BEDNARCZYK (1996) and KISIEL and KSIĄŻKIEWICZ (2000). The effect of laying period on chemical composition and physicochemical properties of fresh egg content, and also mechanical properties of eggshell, $\mathrm{pH}$ value of egg white and yolk as well as the composition of fatty acids in yolk lipids were not analysed in the two flocks of ducks.

The aim of the present study was to compare the effect of the laying period of twoyear-old light type ducks on some morphological, physical, chemical and physicochemical properties of eggs collected at the beginning ( $6^{\text {th }}$ week) and at the end $\left(22^{\text {nd }}\right.$ week) of the second laying period.

\section{Material and Methods}

In the conservative flocks of ducks keep in the National Research Institute of Animal Production there are two types of populations: Pekin type and light type. Because of considerable differences in the productivity of these types of ducks for the present investigations were used two populations of light type of ducks with similar productivity.

The study was conducted on duck eggs from two conservative flocks, maintained in situ method as a gene bank at the Waterfowl Breeding Farm Dworzyska, belonging to the National Research Institute of Animal Production. Conservative flocks were Orpington ducks and birds designated as KhO (Tab. 1). The KhO population was created in 1979 by crossing Khaki Campbell and Orpington ducks and was kept in the following years as a separate closed population. The aim of this procedure was to obtain a synthetic group so as to preserve the genes of two breeds and to reduce the costs of their management. Such a procedure is justified when the type, size and feather colour of birds are similar The experimental material consisted of eggs collected from two-year-old parental ducks: O1 (Orpington) - 28 eggs and $\mathrm{KhO}-28$ eggs at the $6^{\text {th }}$ ( $n=26$ eggs) and the $22^{\text {nd }}$ ( $n=30$ eggs) week of laying. The eggs from each flock were randomly sampled twice in one day.

The ducks were kept in a windowless poultry house in a controlled environment with no access to an outside run. All birds were fed ad libitum with the same all-mash diets 
for breeding ducks. The all-mash contained $173.45 \mathrm{~g}$ crude protein, $33.09 \mathrm{~g}$ fibre, $33.35 \mathrm{~g}$ fat and $11.15 \mathrm{MJ}$ metabolizable energy per $1 \mathrm{~kg}$ of feed.

Table 1

Characteristics of ducks' flock (Merkmale der Entenpopulationen) (WORLD WATCH LIST - FAO, 2000)

\begin{tabular}{|c|c|c|c|c|c|}
\hline \multirow[t]{2}{*}{ Flock } & \multirow[t]{2}{*}{ Origin of ducks } & \multicolumn{2}{|c|}{$\begin{array}{l}\text { Actual size } \\
\text { of the } \\
\text { population }\end{array}$} & \multirow{2}{*}{$\begin{array}{l}\text { Effective } \\
\text { size of } \\
\text { the popu- } \\
\text { lation } \\
\left(\mathrm{N}_{\mathrm{e}}\right)^{*}\end{array}$} & \multirow[t]{2}{*}{ Characteristics } \\
\hline & & $\mathbf{n}_{+}$ & $\mathrm{n}_{\hat{\partial}}$ & & \\
\hline O1 & $\begin{array}{l}\text { Orpington - } \text { yellow- } \\
\text { brown variety, from the } \\
\text { parental flock imported } \\
\text { from France in } 1971\end{array}$ & 80 & 20 & 64 & $\begin{array}{l}\text { The oldest material of duck of strange origin } \\
\text { preserved in Poland, kept without selection for } \\
\text { performance traits. Body weight of adult birds } \\
\text { amount c.a. } 2050\left(\sigma^{\pi}\right) \text { and } 1900 \mathrm{~g}(+) \text {. } \\
\text { Average laying amounting up to } 141 \text { eggs in } \\
\text { first and } 126 \text { eggs in second year of laying } \\
\text { performance respectively. Average egg weight } \\
73.0 \mathrm{~g} \text {. }\end{array}$ \\
\hline KhO & $\begin{array}{l}\text { Crossbreed ducks being a } \\
\text { cross of } 50 \% \text { Khaki } \\
\text { Campbell (Kh1) and } 50 \% \\
\text { O1 (Orpington) }\end{array}$ & 123 & 40 & 104 & $\begin{array}{l}\text { KhO ducks characterized by brown plumage. } \\
\text { Body weight of adult birds amount } 2000(0) \\
\text { and } 1900 \mathrm{~g}(+) \text {. The ducks lay c.a. } 148 \text { eggs in } \\
\text { first and } 142 \text { eggs in second year of laying } \\
\text { performance. Average egg weight } 74.0 \mathrm{~g} \text {. }\end{array}$ \\
\hline
\end{tabular}

The egg weight (g), egg specific gravity $\left(\mathrm{g} / \mathrm{cm}^{3}\right)$ and egg shape index (expressed in \%, by measuring the width to length ratio) were determined directly after the eggs collection.

The remaining analyses were made after $24 \mathrm{~h}$ of cold storage $\left(3.0-4.0^{\circ} \mathrm{C}\right)$. Eggshell strength (N) and shell deformation (\%) were measured by the quasi-static compression test using an Instron Food Testing Machine System Model 5543 (Instron Ltd., England). The eggs were compressed (on the long egg axis) at a constant speed of 5.0 $\mathrm{mm} / \mathrm{min}$ between the poles by flat steel surfaces (HAMILTON, 1982; ABDALLAH et al., 1993). The eggshell deformation was determined to the nearest $0.001 \%$ as the applied force reached $10.0 \mathrm{~N}$. The breaking strength was determined at the time of eggshell fracture. Both measurements were registered by Merlin material testing software package, which was installed on PC connected to the Instron.

The eggshell was dried for 3 hours at $105^{\circ} \mathrm{C}$ in a KC-65-M type drier. The digital micrometer screw was used to measure eggshell thickness (mm) in 3 point: blunt end, middle part and pointed end. The egg white and yolk index were calculated according to the method described by PIKUL (1994). Egg whites, yolks and shells were weighed on a Radwag WPS $3100 \mathrm{C}$ balance. The percentage of egg white, yolk and eggshell were related to the weight of fresh egg.

The instrumental colour analysis was based on measurement of light reflected from yolk and later transformed into values in the CIE (1986) $L^{*} a^{*} b^{*}$ colour system. An automated Minolta Chroma Meter CR-310 (Minolta Camera Co. Ltd, 2-Chome, Osaka 541 Japan) using light source $\mathrm{D}_{65}$ with $8 \mathrm{~mm}$ measuring cell was to register the $L^{*}$ lightness (assumed to be a lightness variable on a scale from 0 for an ideal black to 100 for an ideal white), $a^{*}$ - redness (represented the degree of redness - if positive or greenness - if negative) and $b^{*}$ - yellowness (represented the degree of yellowness - if positive or blueness - if negative) values.

The basic chemical composition of egg white and yolk (i.e.: moisture and protein content in egg white and yolk and lipids in yolk) was analysed by the standard 
methods by AOAC (1990). The $\mathrm{pH}$ of egg white and yolk were measured by using a digital Metrohm pH-meter 654 series (Metrohm Ltd. CH-9100 Harisau, Switzerland), equipped with a combination type of $\mathrm{pH}$ electrode - Foodtrode series (Hamilton Company in Reno, Nevada USA).

The cholesterol content in yolk was determined using the enzymatic Human test in an extract prepared according to the FOLCH et al. (1956) procedure as modified by WASBURN and NIX (1974). The saponification of cholesterol esters was carried out by the ABELL (1952) method with BEYER et al. (1989) modifications. The absorbance was detected with a Hewlett-Packard 8452 A UV/VIS spectrophotometer, at a wavelength of $500 \mathrm{~nm}$.

The composition of fatty acids was determined using gas chromatography technique with an Agilent Tech. $6890 \mathrm{~N}$ Chromatograph, equipped with a flame-ionization detector. Lipids from yolks were extracted with chloroform (FOLCH et al., 1956). Methyl esters of fatty acids were obtained by esterification of lipid samples according to the SZYMCZAK procedure (1979) as modified by PRESCHA et al. (2001). The methyl esters of fatty acids were separated on a fused silica CP-Sil 88 (Chromopack Netherlands) capillary column $(100 \times 0.25 \mathrm{~mm})$, with helium as the carrier gas. The separation was conducted at the programmed temperature from $165^{\circ} \mathrm{C}$ to $200^{\circ} \mathrm{C}$ at increments of $2^{\circ} \mathrm{C} / \mathrm{min}$. The identification of fatty acids was accomplished by comparison with external standards. The fatty acids were calculated as \% of total fatty acids with the ChemStation v. 4.0 Agilent Technologies program.

Statistical analyses (StatSoft, Inc., 2001, STATISTICA data analysis software system, version 6) included:

a) calculation of the arithmetic means $(\bar{x})$ and standard error of mean (SEM) of the all investigated traits;

b) determination of the significance of differences between means for the investigated traits in analysed flocks (O1 and KhO) and week of laying period $\left(6^{\text {th }}\right.$ and $22^{\text {nd }}$ week) as well as between the laying periods within particular flocks of ducks and between these flocks. Differences were considered as significant an the level of 0.05 and 0.01 ;

c) analysis of variance (ANOVA) on a two-factor design with two levels (with statistics of subclasses), according to the linear model $Y_{i j}=\mu+A_{i}+B_{j}+(A B)_{i j}+$ $e_{i j}$, where: $Y_{i j}$ - value of trait; $\mu$ - overall mean; $A_{i}$ - effect of flock; $B_{j}$ - effect of week of laying; $(A B)_{i j}$ - interaction $e_{i j}$ - residual error.

\section{Results}

It was stated that KhO eggs had greater weight (72.46 g) and specific gravity (1.083 $\left.\mathrm{g} / \mathrm{cm}^{3}\right)$ and thicker eggshell $(0.67 \mathrm{~mm})$ than $\mathrm{O} 1$ eggs $\left(70.64 \mathrm{~g}, 1.081 \mathrm{~g} / \mathrm{cm}^{3}\right.$ and 0.65 $\mathrm{mm}$, respectively) (Table 2). The $\mathrm{O} 1$ eggs were characterized by greater yolk content (by 1.13\%), egg white index and lower eggshell content (by 1.68\%) $(\mathrm{P} \leq 0.01)$ than KhO eggs (Table 2). We observed that the kind of flock did not effect on the mechanical properties of the eggshell (Table 2).

The chemical composition and physicochemical properties of the egg content (Table $3)$ depended on duck origin. The KhO egg white had lower $(\mathrm{P} \leq 0.05)$ protein content (10.56\%) than the $\mathrm{O} 1$ (10.72\%). No significant effect of birds origin on the moisture content of egg white and yolk, protein and lipids in yolk and $\mathrm{pH}$ of the yolk was established. The $\mathrm{O} 1 \mathrm{egg}$ yolks were characterized by a higher $(\mathrm{P} \leq 0.05)$ value of 
photometric lightness $\mathrm{L}^{*}(70.27)$ and lower $(\mathrm{P} \leq 0.01)$ intensity of the red colour $-\mathrm{a}^{*}$ (1.76) than $\mathrm{KhO}\left(\mathrm{L}^{*}=69.35\right.$ and $\mathrm{a}^{*}=2.91$, respectively) (Table 3).

Table 2

Morphological traits of eggs and mechanical properties of eggshell (Morphologische Eigenschaften der Eier und mechanische Eigenschaften der Eierschale)

\begin{tabular}{|c|c|c|c|c|c|c|c|c|c|c|}
\hline \multirow{4}{*}{ Trait } & \multicolumn{2}{|c|}{$\begin{array}{c}\text { Flock } \\
{[\mathrm{A}]}\end{array}$} & \multicolumn{2}{|c|}{$\begin{array}{c}\text { Week of laying } \\
{[\mathrm{B}]}\end{array}$} & \multicolumn{5}{|c|}{ Flock } & \multirow{4}{*}{ 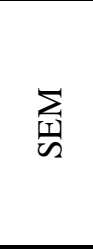 } \\
\hline & \multirow{3}{*}{$\begin{array}{c}\mathrm{O} 1 \\
\mathrm{n}=28\end{array}$} & \multirow{3}{*}{$\begin{array}{l}\mathrm{KhO} \\
\mathrm{n}=28\end{array}$} & \multirow{3}{*}{$\begin{array}{c}6^{\text {th }} \\
n=26\end{array}$} & \multirow{3}{*}{$\begin{array}{l}22^{\text {nd }} \\
n=30\end{array}$} & \multirow{3}{*}{$\stackrel{m}{\frac{m}{x}}$} & \multirow{2}{*}{\multicolumn{2}{|c|}{ O1 }} & \multirow{2}{*}{\multicolumn{2}{|c|}{$\frac{\mathrm{KhO}}{\text { ing }}$}} & \\
\hline & & & & & & & & & & \\
\hline & & & & & & $\begin{array}{c}6^{\text {th }} \\
n=13\end{array}$ & $\begin{array}{l}22^{\text {nd }} \\
n=15\end{array}$ & $\begin{array}{c}6^{\text {th }} \\
n=13\end{array}$ & $\begin{array}{l}22^{\text {nd }} \\
n=15\end{array}$ & \\
\hline Egg weight, g & 70.64 & 72.46 & $73.48^{\mathrm{a}}$ & $69.87^{b}$ & ns & $73.78^{\mathrm{a}}$ & $67.91^{b}$ & 73.18 & 71.83 & 0.87 \\
\hline $\mathrm{ESG}, \mathrm{g} / \mathrm{cm}^{3}$ & $1.081^{\mathrm{b}}$ & $1.083^{\mathrm{a}}$ & $1.087^{\mathrm{A}}$ & $1.077^{\mathrm{B}}$ & ns & $1.086^{\mathrm{A}}$ & $1.076^{\mathrm{B}}$ & $1.087^{\mathrm{A}^{*}}$ & $1.081^{\mathrm{B}}$ & 0.001 \\
\hline $\begin{array}{l}\text { Egg shape index, } \\
\%\end{array}$ & 72.22 & 72.58 & 72.47 & 72.34 & x & 71.50 & 72.85 & $73.44^{\mathrm{a}}$ & $71.83^{b}$ & 0.32 \\
\hline $\begin{array}{l}\text { Eggshell } \\
\text { thickness, mm }\end{array}$ & $0.65^{\mathrm{b}}$ & $0.67^{\mathrm{a}}$ & $0.68^{\mathrm{A}}$ & $0.64^{\mathrm{B}}$ & ns & $0.67^{\mathrm{A}}$ & $0.63^{\mathrm{B}}$ & $0.68^{\mathrm{a}}$ & $0.66^{\mathrm{b}^{*}}$ & 0.01 \\
\hline $\begin{array}{l}\text { Eggshell strength, } \\
\mathrm{N}\end{array}$ & 29.67 & 31.17 & $36.20^{\mathrm{A}}$ & $25.42^{\mathrm{B}}$ & ns & $35.29^{\mathrm{A}}$ & $24.81^{B}$ & $37.11^{\mathrm{A}}$ & $26.02^{\mathrm{B}}$ & 0.99 \\
\hline $\mathrm{ED}, \%$ & 0.36 & 0.37 & $0.42^{\mathrm{A}}$ & $0.33^{\mathrm{B}}$ & ns & $0.41^{\mathrm{a}}$ & $0.32^{\mathrm{b}}$ & $0.42^{\mathrm{A}}$ & $0.33^{\mathrm{B}}$ & 0.01 \\
\hline $\begin{array}{l}\text { Eggshell content, } \\
\%\end{array}$ & $7.85^{\mathrm{B}}$ & $9.53^{\mathrm{A}}$ & $8.34^{\mathrm{B}}$ & $9.00^{\mathrm{A}}$ & $x x$ & $7.02^{\mathrm{B}}$ & $8.58^{\mathrm{A}}$ & $9.67^{* *}$ & $9.42^{* *}$ & 0.15 \\
\hline $\begin{array}{l}\text { Egg white } \\
\text { content, \% }\end{array}$ & 42.70 & 44.42 & $44.77^{\mathrm{a}}$ & $42.51^{\mathrm{b}}$ & ns & 43.75 & 41.78 & 45.79 & 43.24 & 0.57 \\
\hline Yolk content, \% & $40.97^{\mathrm{a}}$ & $39.48^{\mathrm{b}}$ & $38.97^{\mathrm{B}}$ & $41.31^{\mathrm{A}}$ & ns & $39.71^{\mathrm{B}}$ & $42.06^{\mathrm{A}}$ & $38.24^{\mathrm{b}}$ & $40.57^{\mathrm{a}}$ & 0.35 \\
\hline Egg white index & $0.08^{\mathrm{a}}$ & $0.07^{\mathrm{b}}$ & $0.07^{\mathrm{b}}$ & $0.08^{\mathrm{a}}$ & ns & $0.07^{\mathrm{B}}$ & $0.09^{\mathrm{A}^{*}}$ & 0.07 & 0.07 & 0.002 \\
\hline Yolk index & 0.39 & 0.39 & $0.38^{\mathrm{B}}$ & $0.40^{\mathrm{A}}$ & ns & 0.38 & 0.40 & 0.39 & 0.40 & 0.004 \\
\hline
\end{tabular}

ESG - egg specific gravity; ED - eggshell deformation; SEM - standard error of mean; ${ }^{\mathrm{a}, \mathrm{b}}$ - mean values for traits in lines followed by different letters differ significantly ( $\mathrm{P} \leq 0.05)$; ${ }^{\mathrm{A}, \mathrm{B}}$ - mean values for traits in lines followed by different letters differ significantly $(\mathrm{P} \leq 0.01)$

Statistically significant differences in lines between mean values in relation to week of laying in the flock at $(\mathrm{P} \leq 0.05) \mathrm{a}-\mathrm{b} ;(\mathrm{P} \leq 0.01) \mathrm{A}-\mathrm{B}$

Statistically significant differences in lines between mean values in relation to flocks in individual week of laying at $\mathrm{P} \leq 0.05 *$; $\mathrm{P} \leq 0.01$ **

Interaction: flock $[\mathrm{A}]$ and week of laying $[\mathrm{B}]-{ }^{\times} \mathrm{P} \leq 0.05 ;{ }^{\times \times} \mathrm{P} \leq 0.01$; ns - not significant

Table 3

Chemical composition and physicochemical properties of eggs (Chemische Zusammensetzung und physikochemische Eigenschaften der Eier)

\begin{tabular}{|c|c|c|c|c|c|c|c|c|c|c|}
\hline \multirow{4}{*}{ Trait } & \multicolumn{2}{|c|}{$\begin{array}{c}\text { Flock } \\
{[\mathrm{A}]}\end{array}$} & \multicolumn{2}{|c|}{$\begin{array}{l}\text { Week of laying } \\
\text { [B] }\end{array}$} & \multirow{4}{*}{ 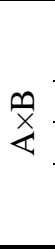 } & \multicolumn{4}{|c|}{ Flock } & \multirow{4}{*}{$\sum_{\substack{[1 \\
\omega}}$} \\
\hline & \multirow{3}{*}{$\begin{array}{c}\mathrm{O} 1 \\
\mathrm{n}=28\end{array}$} & \multirow{3}{*}{$\begin{array}{l}\mathrm{KhO} \\
\mathrm{n}=28\end{array}$} & \multirow{3}{*}{$\begin{array}{c}6^{\text {th }} \\
n=26\end{array}$} & \multirow{3}{*}{$\begin{array}{l}22^{\text {nd }} \\
n=30\end{array}$} & & \multicolumn{2}{|c|}{$\mathrm{O} 1$} & \multirow{2}{*}{\multicolumn{2}{|c|}{$\frac{\mathrm{KhO}}{\text { laying }}$}} & \\
\hline & & & & & & & Week & & & \\
\hline & & & & & & $\begin{array}{c}6^{\text {th }} \\
n=13\end{array}$ & $\begin{array}{l}22^{\text {nd }} \\
n=15\end{array}$ & $n=13$ & $\begin{array}{l}22^{\text {nd }} \\
n=15\end{array}$ & \\
\hline $\begin{array}{l}\text { Egg white moisture, } \\
\%\end{array}$ & 81.14 & 87.12 & 86.93 & 87.40 & ns & 87.45 & 86.72 & 88.08 & 86.40 & 0.39 \\
\hline Yolk moisture, \% & 50.53 & 49.95 & $49.68^{\mathrm{B}}$ & $50.99^{\mathrm{A}}$ & ns & $49.93^{\mathrm{B}}$ & $51.34^{\mathrm{A}}$ & 50.62 & 49.45 & 0.24 \\
\hline Egg white protein, \% & $10.72^{\mathrm{a}}$ & $10.56^{\mathrm{b}}$ & $10.75^{\mathrm{A}}$ & $10.49^{\mathrm{B}}$ & ns & 10.84 & 10.56 & $10.43^{\mathrm{B}}$ & $10.66^{\mathrm{A}}$ & 0.05 \\
\hline Yolk protein, \% & 15.92 & 15.93 & $16.14^{\mathrm{A}}$ & $15.65^{\mathrm{B}}$ & $x$ & $16.08^{\mathrm{A}}$ & $15.73^{\mathrm{B}}$ & $15.56^{\mathrm{B}}$ & $16.21^{\mathrm{A}}$ & 0.06 \\
\hline Yolk lipids, \% & 29.08 & 30.18 & 29.56 & 29.72 & ns & 29.45 & 28.59 & 30.86 & 29.67 & 0.34 \\
\hline $\begin{array}{l}\text { Cholesterol in yolk, } \\
\mathrm{mg} / \mathrm{g}\end{array}$ & 18.56 & 18.18 & $17.35^{\mathrm{B}}$ & $19.73^{\mathrm{A}}$ & ns & $17.60^{\mathrm{b}}$ & $19.85^{\mathrm{a}}$ & $17.10^{\mathrm{b}}$ & $19.61^{\mathrm{a}}$ & 0.38 \\
\hline pH egg white & 8.99 & 8.99 & $9.03^{\mathrm{A}}$ & $8.95^{\mathrm{B}}$ & $x x$ & $9.05^{\mathrm{A}^{*}}$ & $8.93^{\mathrm{b}}$ & 9.01 & 8.97 & 0.01 \\
\hline $\mathrm{pH}$ yolk & 6.36 & 6.36 & $6.40^{\mathrm{a}}$ & $6.32^{\mathrm{b}}$ & ns & $6.93^{\mathrm{a}}$ & $6.32^{\mathrm{b}}$ & 6.40 & 6.32 & 0.02 \\
\hline $\mathrm{L}^{*}$ yolk & $70.27^{\mathrm{a}}$ & $69.35^{\mathrm{b}}$ & $69.31^{\mathrm{b}}$ & $70.24^{\mathrm{a}}$ & ns & 70.03 & 70.48 & $68.59^{\mathrm{b}}$ & $70.00^{\mathrm{a}}$ & 0.20 \\
\hline $\mathrm{a}^{*}$ yolk & $1.76^{\mathrm{B}}$ & $2.91^{\mathrm{A}}$ & 2.32 & 2.35 & ns & 1.39 & 1.06 & $3.24^{* *}$ & 2.63 & 0.19 \\
\hline b* yolk & 39.62 & 39.42 & $40.39^{\mathrm{a}}$ & $38.77^{b}$ & ns & $40.99^{\mathrm{A}}$ & 38.44 & $39.81^{\mathrm{B}}$ & 39.07 & 0.34 \\
\hline
\end{tabular}


The kind of flock influenced on the profile of fatty acids in yolk (Table 4). The UFA were predominant in yolk lipids from both flocks, which amounted to 68.95\% (O1) and $70.37 \%(\mathrm{KhO})$ of the total content of fatty acids. The main components of UFA were MUFA, among them C 18:1 cis-9. Higher contents of C 18:1 cis-9, C 20:4, C 22:6 $(\mathrm{P} \leq 0.01)$ and $\mathrm{C} 20: 5(\mathrm{P} \leq 0.05)$ and the lower of $\alpha \mathrm{C} 18: 3(\mathrm{P} \leq 0.01)$ and $\mathrm{C} 18: 1$ trans-11 $(\mathrm{P} \leq 0.05)$ in $\mathrm{KhO}$ than in $\mathrm{O} 1$ yolks were stated. The UFA/SFA and $\omega-6 / \omega-3$ PUFA ratio in egg yolks of both flocks were similar.

Table 4

Fatty acids composition in egg yolk (Fettsäurenzusammensetzung im Eigelb)

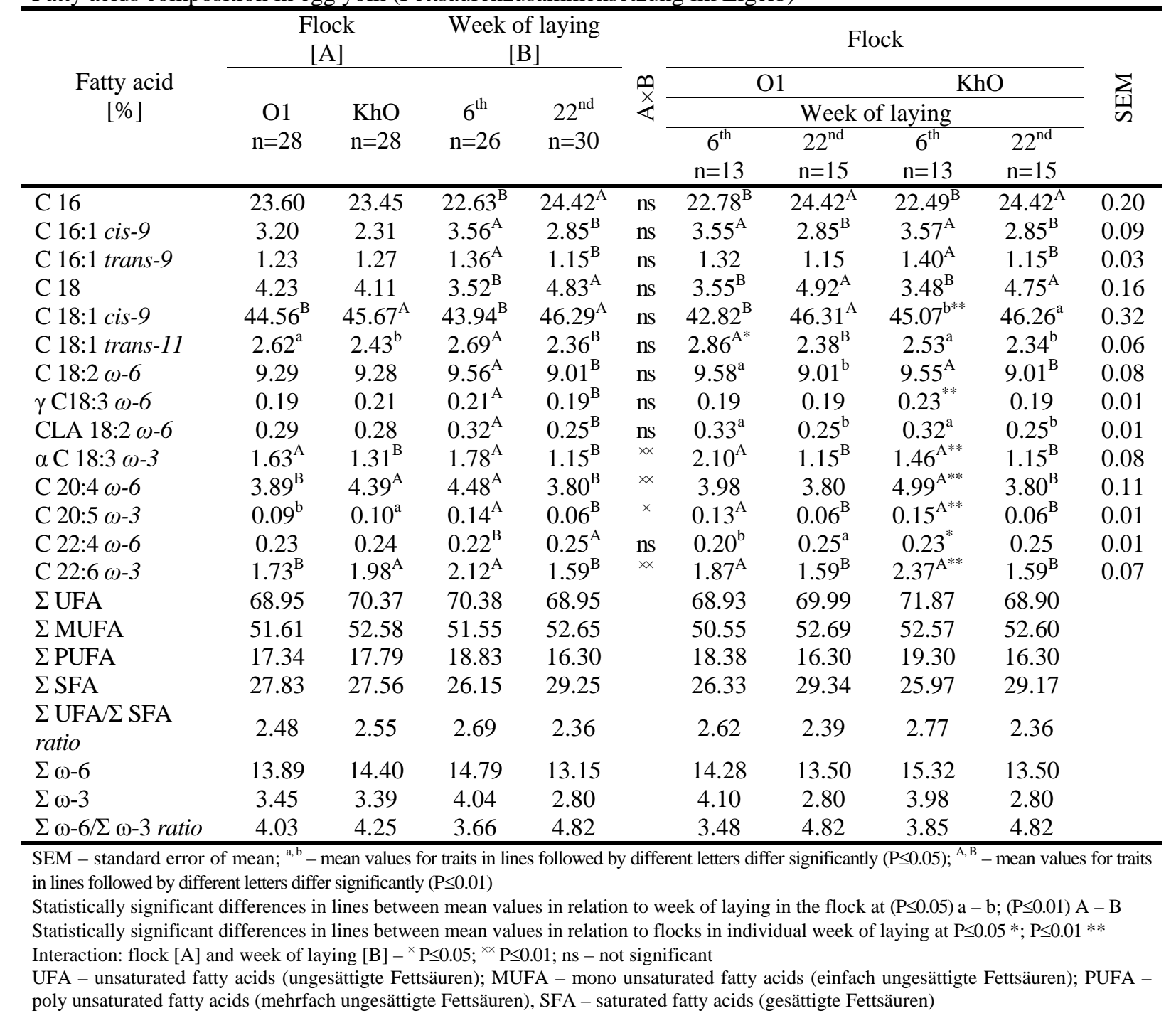

It was established that the eggs laid in the $6^{\text {th }}$ week had a higher weight $(\mathrm{P} \leq 0.05)$, specific gravity and thicker shell $(\mathrm{P} \leq 0.01)$ than those from $22^{\text {nd }}$ week. The eggshell from the $6^{\text {th }}$ week was characterized by higher $(\mathrm{P} \leq 0.01)$ strength and deformation in comparison with $22^{\text {nd }}$ week. The eggs from the $22^{\text {nd }}$ week were characterized by greater $(\mathrm{P} \leq 0.01)$ eggshell and yolk proportion, higher egg white $(\mathrm{P} \leq 0.05)$ and yolk $(\mathrm{P} \leq 0.01)$ index, and lower $(\mathrm{P} \leq 0.05)$ egg white content (by $2.26 \%)$ than from $6^{\text {th }}$ week (Table 2).

Generally, the eggs from the $6^{\text {th }}$ week contained more protein in egg white and yolk and less moisture in yolk in comparison with $22^{\text {nd }}$ week (Table 3). They were also characterized by higher $\mathrm{pH}$ of yolk $(\mathrm{P} \leq 0.05)$ and white $(\mathrm{P} \leq 0.01)$, and lower $\mathrm{L}^{*}$ and 
$\mathrm{b}^{*}$ parameters of yolk $(\mathrm{P} \leq 0.05)$. The eggs from the $6^{\text {th }}$ week contained more UFA and less SFA than from $22^{\text {nd }}$ week (Table 4). We noted more C 16, C 18 and C 18:1 cis-9, total cholesterol $(\mathrm{P} \leq 0.01)$ and less: C 16:1 cis-9 , C 16:1 trans-9, C 18:1 trans-11, CLA 18:2 $(\mathrm{P} \leq 0.01)$ and essential fatty acids, especially C 18:2, C 20:4 and C 22:6 $(\mathrm{P} \leq 0.01)$ in the $22^{\text {nd }}$ than in $6^{\text {th }}$ week of laying. The UFA/SFA ratio was more favourable for egg yolk from the $6^{\text {th }}$ week than for egg yolk from $22^{\text {nd }}$ week. The $\omega$ $6 / \omega-3$ PUFA ratio ranged from $3.66\left(6^{\text {th }}\right.$ week $)$ to $4.82\left(22^{\text {nd }}\right.$ week $)$.

The influence of the week of laying and origin of the ducks on some traits of eggs was analysed separately within the experimental flocks. The $\mathrm{O} 1$ and $\mathrm{KhO}$ eggs laid in the $6^{\text {th }}$ week had a higher weight, specific gravity, thicker shell, lower yolk content and better mechanical properties than the eggs from $22^{\text {nd }}$ week (Table 2). The significantly lower egg white index, higher specific gravity and thicker eggshell were found in the $\mathrm{KhO}$ than in the $\mathrm{O} 1$ eggs laid in $22^{\text {nd }}$ week. The eggshell percentage of $\mathrm{KhO}$ in both weeks of laying was higher $(\mathrm{P} \leq 0.01)$ in comparison with the $\mathrm{O} 1$ eggs.

It was shown (Table 3 ) that $\mathrm{O} 1$ eggs from the $6^{\text {th }}$ week had more protein and less moisture in the yolk than from $22^{\text {nd }}$ week. They were characterized by higher $\mathrm{pH}$ of yolk and egg white and higher value of $b^{*}$ parameter than the eggs from $22^{\text {nd }}$ week. Whereas KhO eggs from $22^{\text {nd }}$ week were characterized by a higher content of protein in yolk and white $(\mathrm{P} \leq 0.01)$ as well as by higher $(\mathrm{P} \leq 0.05)$ lightness of yolk $\left(\mathrm{L}^{*}\right)$ in comparison with eggs from $6^{\text {th }}$ week.

The $\mathrm{O} 1$ eggs from the $6^{\text {th }}$ week had a higher $\mathrm{pH}$ value of egg white $(\mathrm{P} \leq 0.05)$ and lower $\mathrm{a}^{*}$ parameter $(\mathrm{P} \leq 0.01)$ than KhO eggs. Lipids of KhO yolks from $6^{\text {th }}$ week contained more C 18:1 cis-9, $\gamma$ C 18:3, $\alpha$ C 18:3, C 20:4, C 20:5, C 22:6 (P $\leq 0.01)$, C 22:4 $(\mathrm{P} \leq 0.05)$ and less $\mathrm{C} 18: 1$ trans-11 in comparison with the O1 eggs (Table 4). The $\mathrm{O} 1$ and KhO yolks from the $6^{\text {th }}$ week contained more C $16: 1$ cis-9, C 18:1 trans-11 C 18:2, CLA 18:2, a C 18:3, C 20:5, C 22:6, and less C 16, C 18, C18:1 cis-9, C22:4 and total cholesterol than the yolks from $22^{\text {nd }}$ week of laying.

\section{Discussion}

The egg weight of $\mathrm{O} 1$ and $\mathrm{KhO}$ ducks determined in our studies was lower than the weight noted by KSIĄŻKIEWICZ and BEDNARCZYK (1996), who analysed eggs from the same conservative flocks in the second year of use. Shell percentage of KhO eggs was similar and $\mathrm{O} 1$ lower $(\approx 1.60 \%)$ to the results obtained by KISIEL and KSIAZŻKIEWICZ (2000). The investigated eggs were characterized by a lot better eggshell strength in comparison with other kind of ducks - A55, K11 and P77 (MAZANOWSKI et al., 2005). The thickness and shell content in duck eggs, as reported by NIEWIAROWICZ and PŁOTKA (1989), is higher than in hen eggs, whereas the average eggshell strength (measured as a non-destructive deformation) was better in the case of hen eggs. BAIN et al. (2003) stated, that eggshell strength of the eggs from 38-42 week old hens Rhode Island was higher than $\mathrm{O} 1$ and KhO by 9.83 $\mathrm{N}$ and $8.33 \mathrm{~N}$ respectively.

The $\mathrm{pH}$ of egg white of fresh egg from 20-week-old hens Isa Brown Warren layers amounted 8.50 (LAGHI et al., 2003) and was higher than for analysed flocks.

The eggs from the same flocks of ducks in the first year of use (KSIĄŻKIEWICZ and KISIEL, 2002a) were characterized by a lower content of yolk in comparison to results of our investigation. The proportion of moisture in $\mathrm{O} 1$ and $\mathrm{KhO}$ egg yolks was higher than that stated by ROMANOFF and ROMANOFF (1991) (by 5.73\% - O1 and 5.15\% 
- KhO) for duck eggs and similar to this established by PETERSEN et al. (1995) for hens' Lohman LSL and Lohman Brown eggs. However the moisture of egg white and yolk for ducks $\mathrm{O} 1$ and $\mathrm{KhO}$ eggs differed in comparison to the results obtained by DZIADEK et al. (2003) for table eggs from three commercial lines of hens laying (ISA Brown, Shaver 579 and Lohmann Brown).

The protein and lipid contents in yolk were lower $(\approx 1.80 \%$ and $\approx 5.60 \%$, respectively) in comparison with data published by ROMANOFF and ROMANOFF (1991). The higher percentage of lipids in $\mathrm{O} 1$ and $\mathrm{KhO}$ yolks $(\approx 6.0 \%$ and $\approx 7.0 \%$ respectively) was reported by KISIEL and KSIĄŻKIEWICZ (2000).

The cholesterol content in yolks was lower (by $2.14 \mathrm{mg} / \mathrm{g}$ - O1 and by $2.52 \mathrm{mg} / \mathrm{g}-$ $\mathrm{KhO}$ ) in comparison with the results obtained by KSIĄŻKIEWICZ and KISIEL (2002a) for eggs of 54-week-old ducks from the same flocks.

The data on $\mathrm{O} 1$ and KhO yolks were lower for C 16 and C 18:1 cis-9 and higher for C 18:2, C 20:4 and C 22:6 than the data previously published by MALDJIAN et al. (1996) concerning content of fatty acids in yolk of commercial ducks eggs. Furthermore the yolk lipids of investigated eggs contained less SFA (C 16 and C 18) and more C 18:1 trans-11 and long-chain PUFA (mainly C 20:4 and C 22:6) than yolk lipids of eggs from 18-week-old hens Warren line (RIZZI et al., 2003) and Japanese quails - Coturnix coturnix japonica (MENNICKEN et al., 2005). Comparing the profile of fatty acids of lipids, we can conclude, that the $\mathrm{O} 1$ and KhO eggs are favourable from the nutrition point of view.

The weight of the examined eggs (from the $6^{\text {th }}$ and $22^{\text {nd }}$ weeks) was similar to the results obtained by KISIEL and KSIĄŻKIEWICZ (2002a) for eggs laid by two-yearold $\mathrm{O} 1$ and $\mathrm{KhO}$ ducks in the $14^{\text {th }}$ week of laying. In the present study the eggs weight significantly $(\mathrm{P} \leq 0.05)$ declined in the end $\left(22^{\text {nd }}\right.$ week of laying) in comparison to beginning ( $6^{\text {th }}$ week of laying) of the second laying performance of ducks. It is confirmed the results published earlier by KSIAZŻKIEWICZ (2003) who affirmed that egg weight of $\mathrm{Kh} 1, \mathrm{O} 1, \mathrm{KhO}$ and $\mathrm{K} 2$ ducks decreased together with extension of laying performance of birds. We stated that the eggs were characterized by significant differences in eggshell thickness and eggshell strength, depending on the week of laying. These traits significantly decreased as the laying use of birds proceeded. This is in agreement with the results published by CHENG et al. (1995) who found that the shell strength of 30-week-old Brown Tsaiya duck eggs varied from 3.80 to 3.90 $\mathrm{kg} / \mathrm{cm}^{2}$, and was lower $\left(3.40-3.60 \mathrm{~kg} / \mathrm{m}^{2}\right)$ for 40 -week-old ducks. MAZANOWSKI et al. (2005) affirmed too, that eggshell thickness and eggshell strength of eggs from pedigree ducks of parental flock (A 55) and two maternal flocks (P 66 and P 77) decreased on average along with extension of laying performance from $0.396 \mu \mathrm{m}$ and $14.53 \mathrm{~N}$ in $2^{\text {nd }}$ to $0.379 \mu \mathrm{m}$ and $14.00 \mathrm{~N}$ in the $24^{\text {th }}$ week of egg laying. A similar conclusion was made by DE KETELAERE et al. (2003), who found that thickness of hen eggshell (Bovans Brown) decreased by the laying period from $363.40 \mu \mathrm{m}$ in $33^{\text {rd }}$ week to $349.00 \mu \mathrm{m}$ in $78^{\text {th }}$ week of egg laying.

In the present study the proportion of eggshell and yolk was higher and egg white lower in $22^{\text {nd }}$ than in $6^{\text {th }}$ week. MAZANOWSKI et al. (2005) stated an insignificant lower yolk and eggshell content in egg mass laid in the $24^{\text {th }}$ than $2^{\text {nd }}$ week for different kinds of ducks. As reported by LARSEN et al. (1997) moisture and protein content of egg white of White Italian hen layers decreased along with the length of laying period (from $2^{\text {nd }}$ to $4^{\text {th }}$ month). In our studies this dependency was confirmed only for protein 
content in egg white, whereas moisture in egg white and yolk was increased alongside with the extension of period of egg laying. The $\mathrm{pH}$ values of egg white and yolk were significantly lower in the end $\left(22^{\text {nd }}\right.$ week) than at the start $\left(6^{\text {th }}\right.$ week $)$ of investigated laying periods. This is in agreement with the results published by MAZANOWSKI et al. (2005), who stated that the $\mathrm{pH}$ values of egg white and yolk from pedigree ducks of two parental flocks (A44 and A55) and three maternal flocks (P66, P77 and K11) were lower at the start $\left(2^{\text {nd }}\right.$ week $)$ in comparison to the end $\left(24^{\text {th }}\right.$ week $)$ of laying period.

Significant differences were noted between investigated weeks of laying in profile of fatty acids of yolk lipids too. At the end of the reproductive period yolk lipids contained more C 16, C 18 as well as C 18:1 cis-9 and C 22:4 $\omega-6$ and less remaining fatty acids, mainly long-chain PUFA in comparison with yolk lipids of eggs laid at the start of laying period. On the whole during a reproduction the UFA and MUFA content decreased in yolk lipids, and the content of MUFA and SFA increased. Also YANNAKOPOULOS et al. (2005) reported that fatty acids profile of egg yolks (i.e. C 18:2 $\omega-6, \gamma$ C 18: $\omega-6$, C 20:5 $\omega-3$ - EPA and C 22:6 $\omega-3$ - DHA) of Brown Leghorn layers, during one production cycle depended on a week of laying. Furthermore yolk lipids of Brown Leghorn hen layers eggs laid in the $24^{\text {th }}$ week contained more SFA (by 3.73\%), $\omega-6$ fatty acids (by $4.52 \%$ ), and less MUFA and $\omega$-3 fatty acids (by $0.88 \%$ ) in comparison with yolk lipids of analyzed ducks eggs from $22^{\text {nd }}$ week of laying. The $\omega$ $6 / \omega-3$ PUFA ratio ranged from $3.66\left(6^{\text {th }}\right.$ week $)$ to $4.82\left(22^{\text {nd }}\right.$ week $)$ and was close to the recommended values of human diets - 5:1 (FARREL, 1995; GARCIA and CASAL, 1999).

The KhO eggs revealed more favourable physical properties of eggshell (i.e. eggshell thickness as well as eggshell strength and deformation) in comparison with O1 eggs. That's why ducks of KhO flock may serve as a gene resource for selection of improved eggshell stability. Comparing the physicochemical properties, basic chemical composition and profile of fatty acids of yolk lipids it is hard to say, which of the investigated kind of eggs is more profitable, because some parameters were favourable for $\mathrm{O} 1$ and other for KhO eggs. It is evident too, that eggs from both examined flocks have been characterized by high nutritional value.

In spite of the same environmental conditions (i.a. feed and housing conditions) we observed the differences in traits of eggs, evaluation at the start ( $6^{\text {th }}$ week) and in the end $\left(22^{\text {nd }}\right.$ week) of the second laying period. Generally the eggs form the $6^{\text {th }}$ week were characterized by more favourable physical properties of eggshell (especially eggshell strength) and chemical composition, and worse morphological traits of egg (except egg white content) and physicochemical properties - mainly $\mathrm{pH}$ egg white and yolk, in comparison with eggs collected at $22^{\text {nd }}$ week of laying. Taking into consideration the yolk lipids of eggs from $6^{\text {th }}$ week, contained less SFA, and more UFA and PUFA as well as $\omega-6$ and $\omega-3$ fatty acids were more favourable from the nutrition and healthy point of view.

\section{References}

ABDALLAH, A.G.; HARMS, R.H.; EL-HUSSEINY, O.:

Various methods of measuring shell quality in relation to percentage of cracked eggs. Poult. Sci. 72 (1993), 2038-2043

ABELL, L.:

A simplified method for the estimation of total cholesterol in serum and demonstration of its specificity. J. Biol. Chem. 195 (1952), 357-366 
Official Methods of Analysis $15^{\text {th }}$ ed. Association of Official Analytical Chemists. Washington, D.C., (1990)

BAIN, M.; DUNN, I.C.; EDMOND, A.; WILSON, P.W.; JOSEPH, N.; WADDINGTON, D.; SOLOMON, S.; DE KETELAERE, J.; PRESINGER, R.:

Marker assisted selection to improve eggshell quality: Establishing the association between egg phenotypic traits and candidate genes. In: Egg and egg products quality. Proc. $\mathrm{X}^{\text {th }}$ Europ. Symp. on the Quality of Eggs end Egg Products (2003), 126-131

BEYER, R.S.; JENSEN, L.S.:

Overestimation of the cholesterol content of eggs. J. Agric. Food Chem. 37 (1989), 917-920

CHENG, Y.S.; ROUVIER, R.; POIVEY, J.P.; TAI, C.:

Genetic parameters of body weight, egg production and shell quality traits in the Brown Tsaiya ducks. Genet. Select. Evolut. 27 (1995), 459-472

CIE:

Colorimetry, Commission International de l'Eclairage. Publication CIE 15.2, $2^{\text {nd }}$ ed. (1986), Viene

DZIADEK, K.; GORNOWICZ, E.; CZEKALSKI, P.:

Chemical composition of table eggs as influence by the origin of laying hens. Pol. J. Food Nutr. Sci. 12/53 (2003), 21-24

DE KATELAERE, B.; GOVAERTS, T.; KEMPS, B.; MARTENS, K.; BAMELIS, F.; KAMERS, B.; KOKOU, T.; DECUYPERE, E.; DE BAERDEMAKER, J.:

Eggshell quality evolution during the laying period with special attention to within and between hen variability. Proc. $X^{\text {th }}$ Europ. Symp. on the Quality of Eggs end Egg Products (2003), 132-138

FARREL, D.J.:

The problems and practicalities of producing an omega (n)-3 fortified egg. In: Egg and egg products quality. In: Egg and egg products quality. Proc. VI ${ }^{\text {th }}$ Europ. Symp. on the Quality of Eggs end Egg Products (1995), 351-360

FOLCH, J.; LESS, M.; STANLEY, G.H.:

A simple method for the isolation and purification of total lipids from animal tissues. J. Biol. Chem. 226 (1956), 479-509

GARCIA, P.T.; CASSAL, J.J.:

Contribution of poultry lipids to current recommendations for an optimum lipid dietary intake. Proc. $45^{\text {th }}$ Int. Cong. of Meat Sci. and Technol. (1999), 658-659

HAMILTON, R.M.G.:

Methods and factors that affect the measurement of eggshell quality. Poult. Sci. 31 (1982), 2022-2039

KISIEL, T.; KSIĄŻKIEWICZ, J.M.:

Selected egg quality traits of light type ducks from conservative flocks in parent and progeny generations (in Polish). Rocz. Nauk. Zoot. (S), 16 (2002), 121-125

KISIEL, T.; KSIĄŻKIEWICZ, J.M.:

Relationships between selected morphological traits of eggs and biochemical traits of duck egg yolks from different conservative flocks (in Polish). Folia Univ. Agric. Stetin. 207 Zootechnica. 38 (2000), 33-40

KISIEL, T.; KSIĄŻKIEWICZ, J.M.:

Comparison of physical and qualitative traits of meat of two Polish conservative flocks of ducks. Arch. Tierz., Dummerstorf 47 (2004), 367-375

KSIĄŻKIEWICZ, J.M.:

Comparison of reproduction and carcass traits in light type of ducks of four conservative flocks over eight generations. Arch. Tierz., Dummerstorf 46 (2003) 4, 377-389

KSIĄŻKIEWICZ, J.M.; KISIEL, T.:

Some physical and biochemical traits of eggs and their relationship in light type ducks (in Polish). Folia Univ. Agric. Stetin. 227 Zootechnica. 44 (2002a), 77-82

KSIĄŻKIEWICZ, J.M.; KISIEL, T.:

Characteristics of selected morphological and biochemical traits of eggs and their relationships in different Pekin type ducks (in Polish). Folia Univ. Agric. Stetin. 227 Zootechnica. 44 (2002b), 69-76

KSIAZŻKIEWICZ, J.M.; STĘPIŃSKA, M.; KISIEL, T.; RIEDEL, J.: Physical properties of eggs and egg yolk lipids in conservative flocks of Pekin ducks and in a flock of Cayuga ducks (in Polish). Rocz. Nauk. Zoot. 23 (1999) 3, 99-110

KSIĄŻKIEWICZ, J.M.; BEDNARCZYK, M.:

Certain physical egg traits of ducks from twelve preserve groups (in Polish). Pr. Mat. Zoot. 49 (1996), 101-108

KSIĄŻKIEWICZ, J.M.:

Reproductive traits of ducks from genetic reserve in situ. J. Apel. Genet. 36A (1995), 89-90

LAGHI, L.; CREMONINI, M.A.; SYKORA, S.; FRANCHINI, A.; PLACUCCI, G.: 
NMRD study on hen egg albumen. In: Egg and egg products quality. Proc. $X^{\text {th }}$ Europ. Symp. on the Quality of Eggs end Egg Products (2003), 119-124

LARSEN, L.B.; HAMMERSHØJ, M.; WEBER, I.; SCHYUM, P.:

Composition of proteins in albumen in relation to characteristics of heat coagulated egg-white gels. Proc. VI ${ }^{\text {th }}$ Europ. Symp. on the Quality of Eggs end Egg Products (1997), 190-197

MALDJIAN, A.; CRISTOFORI, C.; NOBLE, R.C.; SPEAKE, B.K.:

The fatty acid composition of brain phospholipids from chicken and duck embryos. Comp. Biochem. Phys. s. B 115 (1996), 153-158

MAZANOWSKI, A.; BERNACKI, Z.; KISIEL, T.:

Comparing the structure and chemical composition of duck eggs. Ann. Anim. Sci. 5 (2005) 1, 53-66

MENNICKEN, L.; PONSUKSILI, S.; THOLEN, E.; TKI KIM KHANG, N.; STEIER, K.; PETERSEN, J.;

SCHELLANDER, K.; WIMMERS, K.:

Divergent selection for $\omega-3: \omega-6$ polyunsaturated fatty acid ratio in quail eggs. Arch. Tierz., Dummerstorf 48 (2005) 5, 527-534

NIEWIAROWICZ, A.; PŁOTKA, A.:

Duck eggs. 1. Characteristics of macrostructure and amino acid composition (in Polish) Zesz. Nauk. Drob. 6 (1989), 69-77

PETERSEN, J.; WERNER, G.; MENNICKEN, L.:

Weight related shifts of yolk and albumen components during egg storage. In: Egg and egg products PIKUL, J.: quality. Proc. VI ${ }^{\text {th }}$ Europ. Symp. on the Quality of Eggs end Egg Products (2003), 147-154

PIKUL, J.:

Technological evaluation of eggs and egg products (in Polish). AR Poznań, (1994) 21-22

POWRIE, W.D.; NAKAI, S.:

(in Stadelman W.J. and Cotterill O.J.) Egg Science and Technology. Macmillan, London, (1986) pp. 6190

PRESCHA, A.; ŚWIĘDRYCH, A.; BIERNAT, J.; SZOPA, J.:

Increase in lipid in Potato Tubers by 14-3-3 gene overexpression. J. Agric. Food Chem. 49 (2001), 3638-3643

RIZZI, L.; SIMIOLI, M.; BOCHICCHIO, D.; PARAZZA, P.:

The effects of omega-3 fatty acids, iodine and selenium supplementation of laying hen feed on the egg quality. In: Egg and egg products quality. Proc. $X^{\text {th }}$ Europ. Symp. on the Quality of Eggs end Egg Products (2003), 290-296

ROMANOFF, A.L.; ROMANOFF, A.J.:

(In: The eggs technology) The avian egg, (in Polish). WNT Warsaw, (1991) pp. 40

SZYMCZAK, J.:

Simplified method for preparation of methyl esters of fatty acids from plasma of blood for gas chromatography (in Polish). Diagn. Lab. 15 (1979), 221-226

WASHBURN, K.; NIX, D.:

A rapid technique for extraction of yolk cholesterol. Poult. Sci. 53 (1974), 1118-1122

YANNAKOPOULOS, A.L.; TSERVENI-GOUSI, A.S.; YANNAKAKIS, S.; YAMOUSTARIS, A.:

Yolk fatty acid composition of $\omega-3$ eggs during the laying period. In: Egg and egg products quality. Proc. XI ${ }^{\text {th }}$ Europ. Symp. on the Quality of Eggs end Egg Products (2005), 375-378

Received: 2005-09-20

Accepted: 2006-03-22

Corresponding Author

Dr. ANDRZEJ OKRUSZEK

Wroclaw University of Economics, Department of Animal Food Technology, Komandorska 118/120, 53-345 WROCŁAW, POLAND

E-Mail: andrzej.okruszek@ae.wroc.pl 